\title{
PENGGUNAAN TEPUNG LIMBAH LABU KUNING/WALUH (Cucurbita moschata) DALAM PAKAN AYAM PETELUR TERHADAP BERAT TELUR, TEBAL KERABANG, DAN EGG MASS
}

\author{
Meilani Pangemanan, M.E.R. Montong*, E.S. Tangkere, F.S. Ratulangi \\ Fakultas Peternakan Universitas Sam Ratulangi Manado 95115
}

\begin{abstract}
ABSTRAK
Penelitian ini bertujuan untuk mengetahui pengaruh penggunaan tepung limbah labu kuning/waluh (cucurbita moschata) dalam pakan ayam petelur terhadap berat telur, tebal kerabang, dan egg mass. Penelitian ini menggunakan 100 ekor ayam ras petelur umur 42 minggu. Pengukuran ketebalan kerabang telur dilakukan di Laboratorium Teknologi Hasil Ternak, Fakultas Peternakan Universitas Sam Ratulangi. Variabel yang diamati terdiri dari berat telur, tebal kerabang dan egg mass (massa telur). Metode yang digunakan adalah rancangan acak lengkap yang terdiri dari lima perlakuan dan 5 ulangan, Perlakuan yang diberikan yaitu penggantian tepung limbah labu kuning, dengan masing-masing perlakuan adalah $\mathrm{R} 0=$ Ransum dasar tanpa menggunakan tepung limbah labu kuning, R1 $=$ Ransum dasar $98 \%+2 \%$ tepung limbah labu kuning, $\mathrm{R} 2=$ Ransum dasar $96 \%+4 \%$ tepung limbah labu kuning, R3 = Ransum dasar 94\% $+6 \%$ tepung limbah labu kuning, R4 = Ransum dasar $92 \%+8 \%$ tepung limbah labu kuning. Hasil analisis menunjukkan bahwa penggunaan tepung limbah labu kuning pada level $2 \%, 4 \%, 6 \%$, dan $8 \%$ dalam ransum memberikan pengaruh tidak nyata $(\mathrm{P}>0.05)$ terhadap berat telur, tebal kerabang, dan egg mass. Kesimpulannya adalah penggunaan tepung limbah labu kuning sampai level 8\% dalam pakan ayam petelur memberikan hasil yang sama terhadap berat telur, tebal kerabang dan egg mass.
\end{abstract}

Kata kunci : limbah labu kuning (Cucurbita moschata), telur, ayam petelur.

*Korespondensi (corresponding author):

Email : tinemontong@yahoo.co.id
ABSTRACT

EGG WEIGHT, EGGSHELL THICKNESS AND EGG MASS OF CAGED LAYING HENS GIVEN RATION THAT COMPOSED OF BY SITE PRODUCT OF PUMPKIN FLOUR (Cucurbita moschata) The aim of this research was to find out the effect of using by site product of pumpkin flour (cucurbita moschata) in feed of laying hens on egg weight, eggshell thickness and egg mass. One hundred of laying hens, 42 weeks old were used in this research, and this research was conducted. Randomized completely design was used, 5 treatments and 5 repetitions. The treatments were: $\mathrm{R} 0=$ $100 \%$ basal feed, without using by site product of pumpkin flour (BSPPF); R1 $=98 \%$ basal feed $+2 \%$ BSPPF; R2 $=96 \%+4 \%$ BSPPF; $\mathrm{R} 3=94 \%+6 \%$ BSPPF; R4 $=92 \%+8 \%$ BSPPF. The result of analysis shown that, there were no any significant differences on egg weight, eggshell thickness and egg mass within the group of laying hens that given feed composed of $2 \%, 4 \%, 6 \%, 8 \%$ of by site product of pumpkin flour and given $100 \%$ basal feed respectively. The conclusions of this research was pumpkin flour waste up to the level of $8 \%$ in the feed of laying hens give the same result on egg weight, egg shell thickness and egg mass.

Keywords: by site product of pumpkin, egg, laying hens. 


\section{PENDAHULUAN}

Di Indonesia khususnya Sulawesi Utara ayam petelur tidak asing lagi, dimana ayam tipe ini merupakan ayam yang sangat efisien menghasilkan telur. Telur memiliki nilai gizi yang sangat potensial dan ekonomis, karena telur sebagai salah satu sumber protein hewani memiliki komposisi gizi yang cukup lengkap dan berimbang serta harganya terjangkau.

Situasi dan kondisi industri ayam petelur di Indonesia memiliki banyak kendala, diantaranya harga pakan yang kian hari kian meningkat, sehingga berimbas juga pada produktivitas dan kualitas telur. Masalah kualitas telur, terutama kerabang telur yang mudah retak dapat disebabkan jumlah makanan dan asupan gizi yang dibutuhkan ayam petelur belum memadai, terutama kalsium dan fosfor. Penyebab lainnya, walaupun pakan komersial banyak dijual di poultry shop ataupun toko sarana produksi ternak, namun harga pakan meningkat terus sehingga peternak harus membatasi jumlah pembelian pakan yang pada akhirnya berdampak pada pembatasan pemberian pakan pada ternak mereka. Hal ini mengakibatkan peternak mengalami kesulitan dalam mempertahankan usaha peternakan ayam petelur.
Salah satu langkah yang diambil peternak atau pelaku bisnis peternakan ayam petelur adalah meramu pakan (ransum) untuk ternak mereka. Ini berarti, para pelaku bisnis peternakan ayam petelur harus mencari bahan-bahan yang memadai untuk dijadikan bahan baku penyusunan ransum ternak mereka. Sehubungan dengan itu, kami mencoba memanfaatkan limbah labu kuning yang cukup banyak ditemui di daerah Sulawesi Utara.

Ketersediaan limbah labu kuning terus meningkat sejalan dengan meningkatnya konsumsi masyarakat terhadap hasil olahan berbagai jenis makanan dari buah labu kuning. Meski data statistik untuk produksi limbah labu kuning di Indonesia belum ada, tapi tingkat produksi buah labu kuning di Indonesia relatif tinggi, dan produksinya dari tahun ke tahun terus meningkat yaitu pada tahun 1999 produksinya 73.744 ton, pada tahun 2000 naik menjadi 83.333 ton, pada tahun 2001 menjadi 96.667 ton. Pada tahun 2003 dari 103.451 ton meningkat menjadi 212.697 ton dan pada tahun 2006 sampai dengan tahun 2010 menjadi 369.846 ton (Anonimous, 2010a).

Komposisi kandungan zat gizi limbah labu kuning per 100 gram antara lain; Protein 23,14\%, lemak 14,59\%, serat kasar $17,48 \%$, kalsium $0,76 \%$, fosfor 0,75\% (Hasil Analisa Laboratorium Ilmu dan Teknologi Pakan Fakultas Peternakan IPB 
tahun 2015). Dengan melihat potensi produksi labu kuning dan komposisi gizi limbah labu kuning tersebut, maka dirasa cukup tepat untuk menjadikan limbah labu kuning sebagai salah satu bahan pakan alternatif penyusunan ransum ternak ayam petelur. Dengan menjadikan limbah labu kuning sebagai bahan pakan, berarti juga telah membantu mengatasi limbah organik tersebut dan sekaligus memberi solusi dalam mengatasi masalah mahalnya harga pakan komersial.

Dari pembahasan di atas, maka telah dilakukan penelitian tentang penggunaan tepung limbah labu kuning (Cucurbita moschata) dalam pakan ayam petelur terhadap berat telur, tebal kerabang, dan egg mass. Dari penelitian ini diharapkan dapat meningkatkan produksi telur dan kualitas telur yang baik.

\section{MATERI DAN METODE PENELITIAN}

Materi yang digunakan pada penelitian ini adalah ayam ras petelur fase layer umur 42 minggu dari jenis MB 402 sebanyak 100 ekor. Kandang yang digunakan adalah kandang baterai dengan ukuran $37 \times 40 \times 30 \mathrm{~cm}$ yang terdiri dari 25 unit dan setiap unit kandang ditempati 4 ekor ayam. Peralatan yang digunakan yaitu timbangan digital, calliper dan micrometer scrup. Penelitian ini di laksanakan sejak tanggal 26 Agustus s/d 29 Oktober 2015 yang terdiri dari 7 hari masa pendahuluan dan 56 hari masa pengambilan data.

Prosedur penelitian yaitu: kandang yang akan digunakan terlebih dahulu disucihamakan yaitu dibersihkan dari kotoran dengan menggunakan detergen, air, dan kemudian didesinfektan menggunakan air kapur. Setiap pagi dan sore hari wadah air minum dibersihkan dan diisi dengan air minum yang baru.

Ransum perlakuan yang diberikan pada penelitian ini susun setiap hari berdasarkan kebutuhan ayam petelur sebanyak 125 g/ekor/hari dan diberikan sebanyak 2 kali yaitu pada pagi hari pukul 06.30 sebanyak $50 \%$ dan sisanya pada siang hari pukul 14.00 dengan protein $17 \%$ dan energi $2700 \mathrm{Kkal}$ dengan penambahan tepung limbah labu kuning sebanyak $2 \%$, $4 \%$, 6\% dan $8 \%$. Pada setiap perlakuan diberikan ransum dan air minum secara $a d$ libitum, mengontrol serta penambahan pakan dan air minum dilakukan pada pagi, siang dan sore hari. Komposisi bahan pakan ransum kontrol dan ransum percobaan dapat dilihat pada Tabel 2 dan 3, sedangkan untuk komposisi zat-zat makanan ransum percobaan dapat dilihat pada Tabel 4 dan komposisi zatzat dan bahan makanan ransum percobaan dilihat pada Tabel 1. 
Jurnal Zootek (“Zootek” Journal) Vol. 36 No. 2:280 - 288 (Juli 2016) ＩSSN 0852 -2626

Tabel 1. Komposisi Zat-zat dan Bahan Makanan Ransum Percobaan

\begin{tabular}{lcccccc}
\hline Bahan makanan & $\begin{array}{c}\text { Protein } \\
(\%)\end{array}$ & $\begin{array}{c}\text { Lemak } \\
(\%)\end{array}$ & $\begin{array}{c}\text { Serat kasar } \\
(\%)\end{array}$ & $\begin{array}{c}\mathrm{Ca} \\
(\%)\end{array}$ & $\begin{array}{c}\mathrm{P} \\
(\%)\end{array}$ & $\begin{array}{c}\text { ME(Kkal) } \\
/ \mathrm{kg}\end{array}$ \\
\hline Jagung Kuning** & 8.8 & 3.9 & 2 & 0,02 & 0,28 & 3350 \\
Dedak Halus** & 12 & 13 & 12 & 0,12 & 0,5 & 1630 \\
Tepung Ikan** & 60 & 9 & 1 & 5,5 & 0,3 & 2830 \\
$\mathrm{CaCO}_{3} * * *$ & 0 & 0 & 0 & 29,4 & 0 & 0 \\
Konsentrat Cal 9.36*** & 29 & 10 & 7 & 3 & 2 & 2600 \\
T. Limb. Labu Kuning* & 23,14 & 14,59 & 17,48 & 0,76 & 0,75 & 3882,4 \\
\hline
\end{tabular}

* Hasil Analisa Laboratorium Ilmu dan Teknologi Pakan Fakultas Peternakan IPB 2015.

** Hasil Perhitungan Tabel Komposisi Nutrisi Bahan Pakan NRC (1994).

*** Sumber PT. Japfa

Tabel 2. Komposisi Bahan Pakan Ransum Kontrol

\begin{tabular}{lccccc}
\hline \multirow{3}{*}{ Bahan Makanan } & Jagung & Dedak & $\begin{array}{c}\text { Tepung } \\
\text { Ikan }\end{array}$ & $\mathrm{CaCO}_{3}$ & Konsentrat \\
\cline { 2 - 6 } Jumlah (100) & 50 & 12 & 7 & 5 & 26 \\
\hline
\end{tabular}

Tabel 3. Komposisi Bahan Pakan Ransum Percobaan

\begin{tabular}{lccccc}
\hline \multirow{2}{*}{ Bahan Makanan } & \multicolumn{5}{c}{ Jumlah (\%) } \\
\cline { 2 - 6 } & $\mathrm{R}_{0}$ & $\mathrm{R}_{1}$ & $\mathrm{R}_{2}$ & $\mathrm{R}_{3}$ & $\mathrm{R}_{4}$ \\
\hline Ransum Basal & 100 & 98 & 96 & 94 & 92 \\
T. Limb Labu Kuning & 0 & 2 & 4 & 6 & 8 \\
\hline Total & 100 & 100 & 100 & 100 & 100 \\
\hline
\end{tabular}

Tabel 4. Komposisi Zat-zat Makanan Ransum Percobaan

\begin{tabular}{lccccc}
\hline \multirow{2}{*}{ Komposisi Zat-zat Makanan } & \multicolumn{5}{c}{ Persentase (\%) } \\
\cline { 2 - 6 } & $\mathrm{R}_{0}$ & $\mathrm{R}_{1}$ & $\mathrm{R}_{2}$ & $\mathrm{R}_{3}$ & $\mathrm{R}_{4}$ \\
\hline Protein & 17,58 & 17,69 & 17,80 & 17,91 & 18,02 \\
Lemak & 4,33 & 4,54 & 4,74 & 4,95 & 5,15 \\
Serat kasar & 6,74 & 6,95 & 7,17 & 7,38 & 7,60 \\
Ca & 2,66 & 2,62 & 2,58 & 2,55 & 2,51 \\
P & 0,74 & 0,74 & 0,74 & 0,74 & 0,74 \\
ME (Kkal) & 2745,00 & 2767,75 & 2790,50 & 2813,24 & 2835,99 \\
\hline
\end{tabular}


Proses pengolahan tepung limbah labu kuning yaitu :

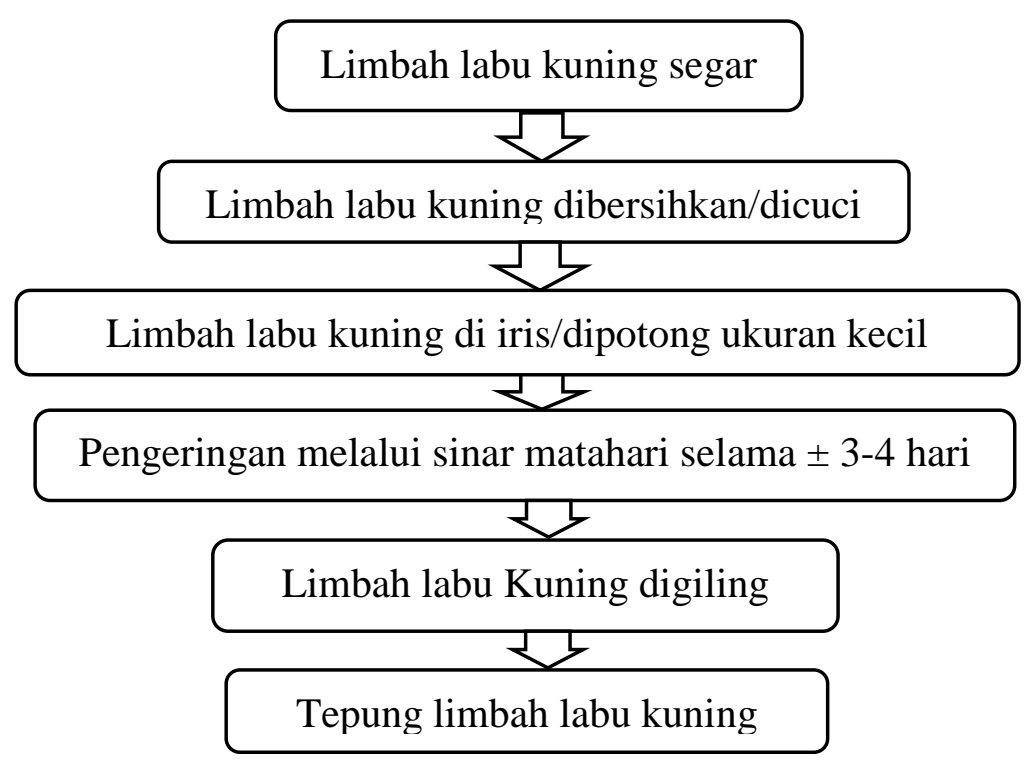

Gambar 1. Skema Pembuatan Tepung Labu Kuning

Pengambilan telur dilakukan pada pagi hari pukul 10.00 dan sore hari pukul 16.00, sedangkan pengambilan telur untuk analisis ketebalan kerabang dilakukan seminggu sekali selama periode penelitian. Setiap perlakuan diambil 1 butir telur sebagai sampel untuk dianalisis ketebalan kerabang di Laboratorium Teknologi Hasil Ternak, Fakultas Peternakan Universitas Sam Ratulangi.

\footnotetext{
Metode yang digunakan pada penelitian ini adalah rancangan acak lengkap (RAL) dengan 5 perlakuan dan 5 ulangan menurut Steel and Torrie (1991). Masing-masing perlakuan yaitu : $\mathrm{R} 0=$ Ransum dasar tanpa menggunakan tepung limbah labu kuning, R1 = Ransum dasar
}

$98 \%+2 \%$ tepung limbah labu kuning, R2 $=$ Ransum dasar $96 \%+4 \%$ tepung limbah labu kuning, R3 = Ransum dasar 94\% + 6 $\%$ tepung limbah labu kuning, R4 = Ransum dasar $92 \%+8 \%$ tepung limbah labu kuning. Variabel yang diamati pada penelitian ini meliputi :

1. Berat telur merupakan perbandingan antara jumlah berat telur yang dihasilkan (g) dengan jumlah telur yang dihasilkan (butir) (North dan Bell, 1990)

2. Tebal kerabang (mm) dilakukan pengukuran ketebalan kerabang dengan menggunakan micrometer skrup, sehingga didapatkan ketebalan kerabang telur. 
3. Massa telur (g/ekor/hari) merupakan hasil kali antara berat telur dengan HDP (Amrullah, 2004).

\section{HASIL DAN PEMBAHASAN}

\section{Pengaruh Perlakuan Terhadap Berat} Telur

Hasil pengamatan dan perhitungan dari masing-masing perlakuan yang diberikan selama penelitian dapat di lihat pada Tabel 5. Menurut Sarwono (1994) berat telur ayam digolongkan menjadi beberapa kelompok sebagai berikut : 1) Jumbo, dengan berat 65 gram per butir; 2) Ekstra besar, dengan berat 60-65 gram per butir; 3) Besar, dengan berat 55-60 gram per butir; 4) Sedang, dengan berat 50-55 gram per butir; 5) Kecil, dengan berat 4550 gram per butir, dan 6) Kecil sekali, dengan berat di bawah 45 gram per butir. Walaupun berat telur dan ukuran telur berbeda-beda, akan tetapi antara berat dan ukuran telur saling berhubungan.

Rataan berat telur pada perlakuan berkisar antara 58-59 gram. Oleh karena itu, rataan berat telur ayam ras pada penelitian ini masih termasuk pada kategori besar/large yang dikemukakan oleh Sarwono (1994), yaitu dengan berat 55-60 gram per butir.

Berdasarkan hasil analisa sidik ragam menunjukkan bahwa penggunaan tepung limbah labu kuning pada level 2-
$8 \%$ memberikan pengaruh yang sama $(\mathrm{P}>0.05)$ terhadap berat telur. Pengaruh perlakuan yang tidak nyata terhadap berat telur pada penelitian ini menunjukan bahwa penggunaan sampai $8 \%$ tidak mengalami peningkatan atau penurunan konsumsi ransum dalam arti kandungan nutrisi zat-zat makanan seperti protein, lemak, asam-asam amino yang diberikan pada setiap perlakuan masih pada standar mutu pakan ayam petelur. Sehingga hal ini tidak mempengaruhi berat telur yang dihasilkan dan pertumbuhan serta produksi telur yang optimum masih dapat tercapai.

Meningkatnya kandungan protein dengan kandungan energi yang sama dapat meningkatkan produksi telur, tetapi tidak berpengaruh terhadap berat telur. Berat telur dipengaruhi oleh beberapa faktor, yaitu genetik, umur induk, pakan, sistem pemeliharaan, dan lingkungan. Oleh karena itu, berat telur semakin meningkat apabila umur ayam meningkat dan kelembaban yang semakin rendah menyebabkan berat telur semakin menurun. Mempertahankan ukuran dan berat telur sesuai dengan standar memang membutuhkan tindakan manajemen pemeliharaan yang tepat. Novak et al. (2006) menyatakan bahwa meningkatnya jumlah konsumsi protein yang seimbang akan meningkatkan ukuran telur dan pemberian tingkat protein tinggi akan 
Tabel 5. Nilai Rataan Variabel Yang Diamati

\begin{tabular}{|c|c|c|c|c|c|}
\hline \multirow{2}{*}{ Variabel } & \multicolumn{5}{|c|}{ Perlakuan } \\
\hline & R0 & $\mathrm{R} 1$ & R2 & R3 & $\mathrm{R} 4$ \\
\hline Berat telur $(\mathrm{g}){ }^{\mathrm{ns}}$ & 58,78 & 59,03 & 59,14 & 59,55 & 58,69 \\
\hline Tebal kerabang (mm) ${ }^{\mathrm{ns}}$ & 0,35 & 0,36 & 0,36 & 0,36 & 0,36 \\
\hline $\operatorname{Egg} \operatorname{mass}(\mathrm{g})^{\mathrm{ns}}$ & 43,81 & 52,87 & 53,28 & 52,49 & 53,35 \\
\hline
\end{tabular}

Keterangan : ns: non signifikan

meningkatkan ukuran telur lebih cepat. Selain itu, berat telur juga dipengaruhi oleh kandungan energi dalam pakan karena pakan yang kandungan energinya tinggi akan menghasilkan telur yang besar.

\section{Pengaruh Perlakuan Terhadap Tebal Kerabang}

Rataan tebal kerabang pada masingmasing perlakuan berkisar antara 0.35-0.36 mm. Hasil penelitian ini tidak jauh berbeda dengan pendapat (Idris dan Thohari, 1998) yang menyatakan bahwa tebal kerabang telur ayam yang ideal yaitu berkisar antara $0,33-0,36 \mathrm{~mm}$.

Berdasarkan hasil analisa sidik ragam menunjukkan bahwa penggunaan tepung limbah labu kuning sampai level 8\% memberikan pengaruh yang sama ( $\mathrm{P}>0.05)$ terhadap ketebalan kerabang. Pengaruh perlakuan yang tidak nyata terhadap tebal kerabang pada penelitian ini menunjukan bahwa kandungan kalsium (Ca) pada tepung limbah labu kuning yang digunakan pada level 2-8\% dalam pakan ayam ras petelur relatif hampir sama sehingga tidak dapat meningkatkan kalsium dalam pakan dan tidak mempengaruhi tebal kerabang telur. Oleh karena itu, kandungan kalsium (Ca) dan fosfor (P) dalam pakan masih pada standar mutu pakan ayam petelur yang baik dan telah cukup terpenuhi.

Kandungan kalsium (Ca) dan fosfor (P) dalam pakan berperan terhadap kualitas kerabang telur karena dalam pembentukan kerabang telur diperlukan adanya ion-ion karbonat dan ion-ion $\mathrm{Ca}$ yang cukup untuk membentuk $\mathrm{CaCO} 3$ kerabang telur. semakin tinggi konsumsi kalsium maka kualitas kerabang telur semakin baik (Clunies et al., 1992). Korelasi antara kekuatan kerabang telur tidakbegitu baik dengan ketebalan kerabang telur (Meyer et al., 2003). Tebal kerabang dipengaruhi oleh kadar $\mathrm{Ca}$ pada ransum, sedangkan penyerapannya dipengaruhi oleh kadar fosfor, dan 
keasaman darah (Muharlien, 2010). Menurut Oguntunji dan Alabi (2010), ketebalan kerabang juga dipengaruhi oleh faktor yang berhubungan dengan sifat genetik, kalsium dalam pakan, dan manajemen seperti temperatur lingkungan, stress, penyakit, dan pakan. Ditambahkan pula oleh Koelkebeck (2003), bahwa Ketebalan kerabang ditentukan oleh kecepatan $\mathrm{Ca}$ dideposit selama pembentukan kerabang dalam uterus. Jika telur hanya sebentar dalam uterus maka ketebalan kerabang rendah dan sebaliknya. Sarwono (1994) menyatakan unggas yang diberi pakan dengan kandungan kalsium tinggi, biasanya menghasilkan kerabang telur yang tebal sedangkan ketebalan kerabang telur akan berpengaruh terhadap berat kerabang. Jadi, kualitas kerabang telur ditentukan oleh ketebalan dan struktur kerabang.

\section{Pengaruh Perlakuan Terhadap Massa} Telur (Egg mass)

Rataan massa telur untuk masingmasing perlakuan berkisar antara 52.49$53.35 \mathrm{~g} /$ hari. Hasil penelitian ini masih berada pada kisaran yang dikemukakan oleh Anonimous (2010b), bahwa rata-rata massa telur pada strain Hy-Line Brown yaitu 50,4-55,3 g/hari.

Berdasarkan hasil analisa statistik sidik ragam menunjukkan bahwa penggunaan tepung limbah labu kuning sampai level $8 \%$ memberikan perbedaan pengaruh yang sama $(\mathrm{P}>0.05)$ terhadap massa telur. Pengaruh perlakuan yang tidak nyata terhadap massa telur pada penelitian ini menunjukan bahwa asupan protein ransum semasa pertumbuhan masih stabil. Oleh karena itu, protein serta asam amino pada masa pertumbuhan masih cukup terpenuhi.

Semakin tinggi berat telur maka semakin tinggi pula nilai egg mass nya, hal ini sesuai dengan pendapat Kartasudjana (2006) yang menyatakan bahwa nilai egg mass tergantung dari produksi telur harian dan berat telur dimana produksi telur dan berat telur akan mempengaruhi massa telur. Apabila egg mass meningkat maka produksi telur meningkat pula sebaliknya egg mass turun produksi telur menurun. Lebih lanjut ditambahkan oleh Amrullah (2004), bahwa penggunaan massa telur (egg mass) dibandingkan jumlah telur merupakan cara menyatakan perbandingan kemampuan produksi antar kelompok atau galur unggas oleh akibat pemberian makanan dan program pengelolaan yang lebih baik.

\section{KESIMPULAN}

Penggunaan tepung limbah labu kuning sampai $8 \%$ dalam pakan ayam petelur dapat digunakan karena memberikan hasil 
yang sama terhadap berat telur, tebal kerabang dan egg mass.

\section{DAFTAR PUSTAKA}

Amrullah, I. K., 2004. Nutrisi Ayam Petelur. Satu Gunung budi. Bogor.

Anonimous, 2010a. Data Statistik Produksi Labu Kuning. BPS Indonesia

Anonimous, 2010b. Hy-Line International Online Management Guid.

Clunies. M., D. Parks and S. Lesson, 1992. Calcium and phosphorus metabolism and egg Shell formation of hens fed different amounts of calcium. Poultry Science 71:482- 489.

Idris, S dan I. Thohari. 1998. Telur dan Cara Pengawetannya. Fakultas Peternakan. Universitas Brawijaya. Malang.

Koelkebeck, K.W. 2003. What is Shell Quality and How to Preseve it. Linin Poultry Net - University of Lilliois.

Kartasudjana, R. 2006. Manajemen Ternak Unggas. Penebar Swadaya, Jakarta

Meyer, R., R.C. Baker and M.L. Scott. 2003. Effects of hen egg shell and other calcium sources upon egg shell strength and ultrastructure. J. Poultry Sci. 62 : 2227-29.

Muharlien, 2010. Improving the egg quality trough addition of green tea in diet on laying hen. Jurnal Ilmu dan Teknologi Hasil Ternak UNIB 5(1): 32-37.

North, M. O. and D. D. Bell. 1990. Commercial Chicken Production Manual. The $4^{\text {th }}$ Ed. Avi Publishing Company Inc. Westport, Connecticut.

Novak, C., H.M. Yakout and S.E. Scheideler. 2006. The effect of dietary protein level and total sulfur amino acid: Lysine ratio on egg production parameters and egg yield in hy-line W-98 hens. J. Poultry. Sci. 85: 2195-2206

Oguntunji, A.O. and O.M. Alabi. 2010. Influence of high environmental temperature on egg production and shell quality: a review. World's Poultry Science Journal. 66: 739750.

Sarwono, B. 1994. Pengawetan Telur Dan Manfaatnya. PT. Penebar Swadaya, Jakarta.

Steel, R.G.D. dan J.H. Torrie, 1991. Prinsip Prosedur Statistika. Gramedia Pustaka Utama, Jakarta. 